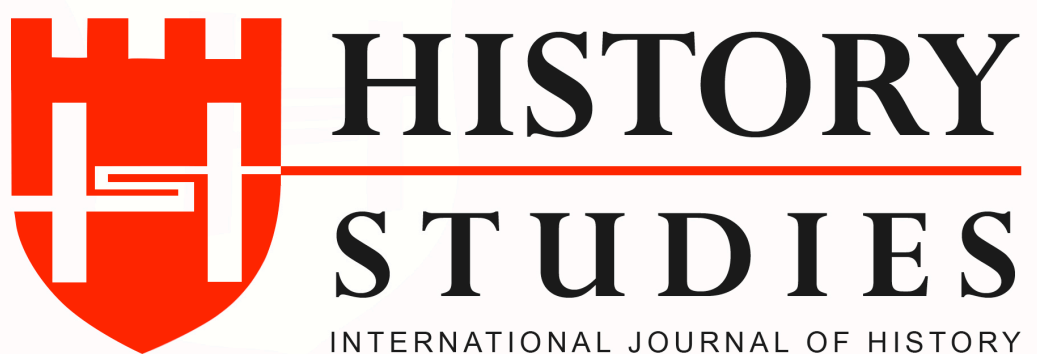

ISSN: 13094173 (Online) 1309 - 4688 (Print)

Volume 12 Issue 1, February 2020

DOI Number: 10.9737/hist.2020.825

Araştırma Makalesi

Makalenin Geliş Tarihi: 05.11.2019 Kabul Tarihi: 09.01.2020

Atıf Künyesi: Alev Duran, "İkinci Dünya Savaşı Sırasındaki Türkiye-Macaristan İlişkileri”, History

Studies, 12/1, Şubat 2020, s. 171-190.

\title{
İkinci Dünya Savaşı Sırasındaki Türkiye-Macaristan İlişkileri
}

\author{
Turkey-Hungary Relations in During The Second World War
}

Dr. Alev Duran

ORCID No: 0000-0003-0995-8090

İstanbul Aydın Üniversitesi

$\ddot{O} \mathbf{z}$

Türkiye'nin ikinci Cumhurbaşkanı olan İsmet İnönü'nün dönemi, Milli Şef Dönemi olarak kabul görmüştür. İnönü’nün göreve gelmesinden sonra Türk dış politikası mevcut statükosunu korumak ve yaklaşan savaştan uzak durmak üzerine kurulmuştur. Bu dönemde Türkiye-Macaristan ilişkileri İkinci Dünya Savaşı'nın etkisi altında gelişme göstermiştir. Macaristan'ın bu dönemde savaşa girmiş olması, iki ülkenin ilişkilerinde gerileme yaşanmasına neden olmuş, ancak Türk-Macar dostluğuna gölge düşürmemiştir. Bu çalışmada, iki ülkenin ilişkileri kronolojik olarak; siyasi ve diplomatik ilişkiler, savaş sonrası yaşanan gelişmeler, ekonomik ve ticari ilişkiler, kültürel ve sosyal ilişkiler olmak üzere başlıklar altında toplanmıştır.

Anahtar Kelimeler: Türkiye, Macaristan, Dış İlişkiler, Türk-Macar İlişkileri, İkinci Dünya Savaşı

\begin{abstract}
Ismet Inönü's period, the second President of theTurkis Republic was accepted as the period of the National Chief Period. After Inönü's referral, Turkish foreign policy was based on protecting the current statusquo and avoiding the approaching war.In this period, theTurkey-Hungary relations have developed under the influence of the Second World War. Ismet Inönü, as an experienced commanderand a statesman gave great effort to stay out of the Secon World War. Hungary has entered the war in this period, led to decline in relations between to countries, but it did not cast a shadow over theTurkish-Hungarian friendship. In this study, the relations of the two countries were examined chronologically political and diplomatic, economic and commercial relations, cultural and social relations and Hungarian experts work in in various institutions.
\end{abstract}

KeyWords: Turkey, Hungary, Foreign Relations, Turco-Hungarian Relations, Second World War

\section{Giriş}

Atatürk'ün vefatından sonra, 11 Kasım 1938'de İsmet İnönü’nün Cumhurbaşkanı seçilmesiyle, Cumhuriyet Halk Partisi'nde Genel Başkanlık için de seçim yapılmasına gidilmiş, 26 Aralık'ta toplanan kurultayda İsmet İnönü partinin değişmez Genel Başkanı seçilmiştir. Bundan sonra İsmet İnönü'nün idaresinde tek parti yönetiminin, hayatın her 
alanında söz sahibi olduğu, politikayı bizzat ve doğrudan doğruya idare ettiği, Milli Şef dönemi başlamıştır. ${ }^{1}$

İkinci Dünya Savaşı döneminde, iki ülkenin dış politika yönelimleri farklı bir seyir izlemiş ve bunun sonucunda iki ülke tamamen farklı iki yöne doğru ilerlemiştir. İnönü görevine başladığında, Türkiye'nin dıș politikası, Atatürk'ün belirlemiş olduğu dıș politika ekseninde devam etmiş, yaklaşan İkinci Dünya Savaşı'ndan dolayı ise özelde ihtiyat esasına dayandırılmıştır. Bu dönem de, Türk dış politikası etrafında, Lozan'da kurulan statükonun devamı ve savaş dışı kalınması esasına dayalı iki ana unsur olarak şekillenmiştir. Macaristan'ın ise, savaş öncesinde özellikle Almanya başta olmak üzere çeşitli ülkelerin hedefi haline geldiği ifade edilebilir. Türkiye'nin savaş dışı kalmaya çalıştığı bu dönemde, savaşta yer alan Macaristan ile ilişkileri gerilemişse de, Türk-Macar ilişkilerinde bir problem yaşanmadığ 1 gibi, Türk-Macar dostluğuna da gölge düşmemiştir.

Türk-Macar ilişkilerinin savaştan etkilenmemesinin en önemli nedeni, iki ülke arasındaki ilişkilerin köklü bir tarihsel mirasa dayanmasıdır. Tarihin en eski dönemlerinden itibaren ilişki halinde olan bu iki halk, Türklerin, Macaristan'ı fethetmesiyle birlikte yüz elli yıldan fazla iç içe yaşamıştır. Türklerin, Macar topraklarından çekilmesinden sonra ise, Habsburg yönetimi altına giren Macar halkı, yönetimin dayatmış olduğu baskıya karşı başarısızlıkla sonuçlanan ayaklanmalarında, Osmanlı Sultanlarının himayesine sığınmışlardır. Macar mültecilerine Osmanlı Sultanların göstermiş olduğu ilgi ve alaka, Macar halkının kalbinde silinmez izler bırakmıştır. $^{2}$

Birinci Dünya Savaşı'nda iki halkın müttefik olması siyasi ve askeri ilişkilerin yanı sıra, kültürel ve ekonomik alanda da iyi ilişkiler kurulmasını sağlamıştır. Bunun en güzel örneği de yeni kurulan Türkiye Cumhuriyeti'ni ilk tanıyan devletlerden biri olan Macaristan'la imzaladığı ilk dostluk anlaşmasıdır. Atatürk Dönemi'nde iki ülke ilişkileri siyasi, ekonomik ve kültürel alanlarda gelişerek ilermiş, ikili ilişkiler karşılıklı dostluk ve kardeşlik temeli üzerine oturtulmuştur. ${ }^{3}$

$\mathrm{Bu}$ çalışmada İsmet İnönü döneminde Türkiye-Macaristan ilişkileri dört başlık altında incelenmiştir. Bunlar sırasıyla; siyasi ve diplomatik ilişkiler, ekonomik ve ticari ilişkiler, kültürel ve sosyal ilişkiler, çeşitli kuruluşlarda çalıştırılan Macarlar olarak tespit edilmiştir.

\section{Siyasi ve Diplomatik İlişkiler}

İnönü'nün Cumhurbaşkanı olmasından sonra, iki ülke arasındaki ilk temaslar, Cumhuriyetin kurucusu Mustafa Kemal Atatürk'ün vefatı üzerine gönderilen taziye mesajları olmuştur. Dönemin Macaristan Devlet Başkanı Miklós Horty, TBMM Başkanı'na gönderdiği samimi başsağ lı̆̆ mesajı ile Türk milletinin acısına ortak olmuş, ayrıca özel kalem müdürünü de Türkiye'nin Budapeşte Elçisi Enis Behiç Erkin'e göndermiştir. Mustafa Kemal Atatürk’ün cenaze töreninin yapılacağı 21 Kasım 1938 tarihi Macar Başbakan Imredi tarafından Macaristan'da ulusal yas günü ilan edilmiş, Macaristan'daki tüm resmi binalar siyah bayrak çekerek yas tutmuştur. ${ }^{4}$

${ }^{1}$ Cemil Koçak, Türkiye'de Milli Şef Dönemi (1938-1945), C. 1, İletişim Yayınları, İstanbul 2012, s.164.

${ }^{2}$ György Hazai, Tarih Boyunca Macar-Türk Bağları, Budapest 1963, s.22

3 Melek Çolak, “ Atatürk Döneminde Kültürel, Siyasi ve Ekonomik Bakımdan Türk-Macar İlişkileri (1919-1938)”, Muğla Üniversitesi Sosyal Bilimler Enstitüsü Dergisi, C.1, S.2, Güz 2000, ss.61-72.

${ }^{4}$ Melek Çolak, “ Atatürk'ün Vefatı ve Macaristan'daki Yankıları”, Atatürk Araştırma Merkezi Dergisi, Say1:57, Kasim 2003, s. 1012-1014. 
1939 yılında İkinci Dünya Savaşı'nın patlak vermesinden sonra Türkiye-Macaristan İlişkileri savaşın getirdiği atmosferde ilerlemiştir. Macar Hükümeti, Türkiye'nin savaş karşısındaki tutumunu yakından izlemiştir. Cumhurbaşkanı İnönü'nün 26 Ocak 1943'te İngiltere Başbakanı Churcill ile Adana'da yapmış olduğu görüşme, yarı resmi Macar gazetesi Pester Llyold'de yer almıştır. ${ }^{5}$ Macaristan'ı savaşın dışında tutmaya çalışan dönemin Başbakanı Miklós Kállay, Türkiye'nin savaş dışı ülke olmasından yararlanarak, İstanbul'u gizli müzakere üssü olarak görmüş, bu yolla diğer ülkelerle işbirliği yaparak savaş dişı kalmaya çalışmıştır. ${ }^{6}$

Ruşen Eşref Ünaydın'ın Peşte elçiliği görevi 1943 yılında sonra erdiğinde, Horty tarafından kendisine Aziz István nişanının büyük rütbesiyle taltif edilmiş, Başbakan Kállay’da Ünaydın'ın şerefine bütün kordiplomatiğin, Macar Bakanların, askeri ve mülki şahısların katıldığ 1 bir yemek tertip etmiştir. ${ }^{7}$ Yeni elçi Şevked Fuad Keçeci gelinceye kadar elçilik başkatibi Said Kemal Bey, maslahatgüzar sıfatıyla elçilik işlerini idare etmiştir. ${ }^{8}$ Bu dönemde Macaristan'ın Türkiye elçisi olarak Zoltan Mariassy görevde bulunmuştur. 1943 yılında Zoltan Mariassy'in yerine, Ankara'ya, Jean Vörnle tayin edilmiştir. ${ }^{9}$

İkinci Dünya Savaşının ateşli bir şekilde devam ettiği 1943 yılında Macar basınında Türkiye'nin lehine haberlere yer verilmiştir. Türk basınına da yansıyan Az Orszag isimli haftalık gazetenin haberinde, Türkiye Cumhuriyeti Cumhurbaşkanı İsmet İnönü’nün devlet adamı, asker ve yeni Türkiye'nin çığır açıcı sıfatı ile haiz olduğu kudreti belirtmiştir. Haberde; “ Tarafsızlı̆̆ın muhafazası İn̈̈ü'nün devlet adamı sifatı ile başardığ en büyük iştir ve bu siyaset sayesinde Türkiye istikbalde büyük bir rol oynayacaktır. Asker sıfatı ile İnönü azametli bir taktik kullanmış ve ordunun son senelerde az zaman içinde yeniden teşkilatlandırllmasında eşsiz bir başarı yaratmış, eski düşmanlarını bile hayrete düşürmüştür. Birçok eserlere mevzu teşkil eden İnönü meydan muharebesi bütün askeri mekteplerde önemli bir tez olarak ögretilmekte ve İsmet Paşa'nın zafere yürüdü̈̆̈̈ yolu gösteren düşünce en parlak bir askeri başart olarak antlmaktadır. Kemal Atatürk ve İsmet Inönü yeni bir Türk milleti vücuda getirmişler ve Türkiye'den bir büyük devlet yaratmışlardır." ifadeleri yer almıştır.

Macar devlet adamları ve diplomatları müttefik devletlerle temasa geçmiş ${ }^{10}$ ve Macar Hükümeti'nin temasa geçtiği diğer bir devlette Türkiye olmuştur. Başbakan Kállay, 1943 yılının Temmuz ayında Ullein'in, etnik ilişkilere ve geleneksel siyasi dostluk temeline dayanan bir Macar-Türk Antantı kurmasını isteyerek Türkiye'ye göndermiştir, fakat Ullein'in bu konudaki girişimi Almanları ürkütmüş ve Türkler de savaş dışı kalmaya çalıştıklarından gerçekleşmemiştir. ${ }^{11}$

Macaristan'ın Türkiye'den bir diğer yardım isteği ise, eski Macar elçisi olan ve Macaristan'da da Türk dostu olarak tanınan Enis Behiç Erkin'in Fransa'daki görevinden

\footnotetext{
5 Osman Yalçın, “ İkinci Dünya Savaşı'nda İsmet İnönü ve Churchill Arasında Yapılan Adana Görüşmesi”, Ankara Üniversitesi Türk Inkılâp Tarih Enstitüsü Atatürk Yolu Dergisi, S.47, Bahar 2011, s. 717.

${ }^{6}$ Naciye Güngörmüş, Macaristan'da Değişim ve Demokrasiye Geçiş (1989-2009), Köksav Yayınları, Ankara 2010, s.71; Emre Saral, Türkiye-Macaristan İlişkileri (1920-1945), Yayımlanmamış Doktora Tezi, Hacettepe Üniversitesi, Ankara 2016, s.251.

${ }^{7}$ Saral, a.g.t, s. 250 .

8 “Ruşen Eşref”, Cumhuriyet, 8 Ağustos 1943, s. 1.

${ }^{9} B C A, 30 . .10 .0 .0,130.933 . .16$, Dosya: 11166

${ }^{10}$ A.A Gromıko, I.N Zemskov, V.A Zorin, Uluslararası İlişkiler Tarihi (çev: Ali Rıza Dırık), C. 5, Evrensel Basım Yayın, İstanbul 2013, s.335.

${ }^{11}$ Saral, s.250.
} 
Türkiye’ye, Macaristan üzerinden döndüğü sırada yapılmıştır. Erkin Türkiye’ye dönmeden önce Budapeşte'de kalmış, ve bu zaman zarfında, iki saat kadar süren görüşmelerinde Macar Başbakanı Türkiye'den doğrudan yardım istemiştir: ${ }^{12}$

\begin{abstract}
“(Kállay'ın) bir derdi vardl; müttefikler ileride münasip görecekleri cezayı tatbik etmek şartı ile şimdiden Macaristan, Romanya ve Bulgaristan'in bitaraf telakki edilmesini ve buraların harp meydanı olmamasını istiyor ve bunun müttefiklere teklif edilmesini İsmet Inönü'den rica ediyordu. Müttefiklerin müttefiki olan Yugoslavya ve Yunanistan'ın harp sahası kalarak, müttefiklerin düşmanı telakki edilen Romanya, Macaristan ve Bulgaristan'a böyle bir imtiyaz verilmesini kabul etmeyeceklerini ve bununla beraber bu tekliflerini İsmet İnönü’ye arz edeceğimi söyledim. Kállay’ın bu sözlerinin, Almanya'nın muzaffer olamayacă̆ını inancından ileri geldiğine şüphe yoktur. Esasen Kállay da ComteTelky gibi, Anglo-Sakson taraftar idi. Kállay, bana 'Görüyor musun? Yahudilere bir şey yapılmadl, herkes yerli yerinde oturuyor' demekle de Macaristan'in Almanların her arzusuna itaat etmediklerini anlatmak istedi. Kendisinin malikanesinde bulunduğunu, birkaç gün sonra Budapeşte'ye geleceğini ve eşinin beni görmek ve davet etmekle çok memnun olacă̆ını söyledi ise de programını bozmak müskül olduğundan itizar ettim.. (Yurda avdetten sonra İnönü ve Saraçoğlu’na) Macar Başvekili Kállay'ın söylediklerini arz ettim; “ Bunları bir rapor şeklinde Haricye'ye vereyim mi?' dedimse de lüzum görmediler.'
\end{abstract}

Türkiye 2 A ğustos 1944 tarihinde Almanya ile diplomatik ilişkilerini kesmiş ve iyi ilişkiler sürdürdüğü Almanya müttefiki olan Macaristan'la ise ilişkilerini muhafaza etmek istemiştir. $\mathrm{Bu}$ dönemde Macarlar da Türklerle olan iyi ilişkilerini sürdürmek istediklerini dile getirmişlerdir. ${ }^{13}$ Dönemin Macar Başbakanı Döme Sztójay, Almanya'nın "Türkiye ile diplomatik ilişkilerini kesme" talebini reddetmiştir. ${ }^{14}$

Macaristan'da yaşanan işgal nedeniyle Macaristan sabık Başbakanı Miklós Kállay, Alman ve Macar polisleri tarafından tutuklanmak istenince, Türkiye ve İsviçre elçilikleri tarafından sığınmacı olarak kabul edilebileceği bildirilmiştir. Kállay, Türkiye'nin Elçiliğine sığınmış, ${ }^{15}$ 19 Kasım 1944 tarihine kadar, yaklaşık 6 ay, Macaristan'da ki Türk elçilik binasında kalmıştır. 19 Kasım günü Türk hükümetinin daha fazla zor durumda kalmasını istemediğinden, kendi isteğiyle ayrılmış ve tutuklanmıştır. ${ }^{16}$ Kállay'ın tutuklu bulunduğu dönemde, Türk elçiliğinde kalmaya devam eden eşi, şehrin bombardımanı sırasında yaşamını yitirmiş ve Türk sefaretinin bahçesine defnedilmiştir. Bu dönemde İstanbul'da çıkan Yeni Sabah gazetesinde Macar Başbakanı küçük düşürücü bir karikatür yayımlaması üzerine gazete kapatılmıştır. ${ }^{17}$

\footnotetext{
${ }^{12}$ Agt., s.250.

13 Pergel Antal, "Egy magyar barát török diplomata Sevket Fuat Kecsedzsi 1892-1965”, Érdi Lap, XI. évfolyam No. 15 (15 augusztus 2013), s.8 ;"Macarlar Türkiye ile Ananevi Dostluğa Sadık”, Ulus, 7.8.1944, s.2.

${ }^{14}$ Saral, a.g.t.,s.252.

15 Kallay, Macar tarihinde İmre Thököly, Ferenc Rákóczi ve Lajos Kossuth”un ardindan Türkiye’ye sığınan dödüncü Macar siyaset adamı olmuştur. Bkz: Alev Duran- İsmail Köse, "Lajos Kossuth ve Macar Mülteciler”, Selçuklu Araştırmaları Dergisi, USAD, S.6, 2017, s. 291-314

${ }^{16}$ András Joó, “ 20. Yüzyılda Kendisine Sığınma Hakkı Tanınan Macar Başbakanı Miklós Kállay (19421944)", Türkiye’de Kendilerine Sı̆̆ınma Hakkı Tanınan Macar Mültecilerin Özyaşamlarından Özetler, (Çev: Yılmaz Gülen), Magyar-TörökBarátiTársaság, Budapest 2010, s.79-82; Peter Gosztony, “ Horty, Hitler andtheHungary of 1944”, Canadian-AmericanReview of HungarianStudies, No:1, Vol: II, Spring 1975, s.45; "Eski Macar Başvekili",Cumhuriyet,4.4.1944,s.1; Melek Çolak, 1956 Macar Ihtilali ve Türkiye, Nehir Yay, İstanbul 2009, s. 19; Güngörmüş, a.g.e, s. 71-73; Yücel Namal, Türk Kaynakları Işı̆̆ııda Türk-Macar İlişkileri(1923-1950), Yayımlanmış Doktora Tezi, Ankara Üniversitesi, Ankara 2013, s. 205-208.

${ }^{17} B C A, 30.10 .0 .0,86.570 .6$, Dosya:8674, 28/3/1944.
}

\title{
History Studies
}


Türkiye Peşte Elçiliği 1 Nisan 1945 tarihine kadar oldukça zor şartlar altında çalışmış, Macaristan'ın Sovyet güçlerinin kontrolüne geçmesinden sonra ise elçi Şevket Fuat Keçeci ve bütün elçilik çalışanları ve aileleri, Sovyetlerin tahsis etmiş olduğu trenle Macaristan'dan ayrılarak 3 Nisan'da Türkiye'ye gelmişler ve Türkiye-Macaristan diplomatik ilişkilerinin yaklaşık bir yıllık kesintisi de böylece başlamıştır. ${ }^{18}$

\section{Savaş Sonrası Yaşanan Gelişmeler}

İki ülke arasındaki ilişkilerin askıya alınması iki tarafında ilişkilerini geliştirmek istemesi sebebiyle çok uzun sürmemiştir. İlk atak Macaristan'dan gelmiş, ülke otoritesinin sağlanmasının ardından Başbakanlık görevine gelen Zoltán Tildy hükümet programında TürkMacar ilişkilerine de yer vermiş, mümkün olduğu kadar çabuk Türkiye ile olan siyasi ilişkilerini başlatmak istediğini ifade etmiştir. ${ }^{19}$

Ardından Türkiye tarafından da ikinci adım atılmıştır. Türk elçiliğinin Budapeşte'de yeniden açılması için 1946 senesinde Macaristan'a bir heyet gönderilmiştir. Budapeşte elçilik raporlarına göre Budapeşte'ye giden bu ekip yoğun bir ilgiyle karşılaşmıştır. Macaristan basınında Türk elçiliğinin yeniden faaliyete geçecek olması ile ilgili olumlu haberler yapılmasının yanında, çoğu zaman Türklerin Macarlara yapmış olduğu yardımlardan bahsedilmiştir. Heyet, Macaristan Başbakanı Zoltán Tildy ile de bir görüşme gerçekleştirmiştir. Başbakan Tildy'nin heyete karşı tutumu oldukça sıcak olduğu gibi, İsmet İnönü ve Türk Hükümeti'nin İkinci Cihan Harbindeki politikasından da övgüyle bahsetmiştir. ${ }^{20}$

Yapılan görüşmelerde, karşılıklı elçi atamalarına kadar, Türkiye maslahatgüzar olarak Zeki Karabuda'y1, Macaristan'da elçilik işleri için Mösyö Paul Fabry'i Türkiye'ye göndermiştir. Mösyö, 23 Eylül 1946'da Türkiye Dışişleri Bakanlığı''na ziyarette bulunarak, 23 Eylül'den itibaren görevine başladığını bildirmiştir. ${ }^{21}$

1947 yllında Agâh Aksel'in Budapeşte Türk elçiliğinde görevlendirilmesi ile yeniden faaliyetlere geçilerek, Türkiye ile Macaristan arasındaki diplomatik ilişkilerin tekrar tesisi gerçekleştirilmiştir. Agâh Aksel'in onuruna, Peşte'deki Türk-Macar Ticaret Odası tarafindan bir yemek düzenlenmiştir. Tertip edilen bu organizasyona Macar bakanları, üst düzey yöneticiler, banka müdürleri iştirak etmiş, etkinlik boyunca Türk-Macar dostluğu temalı konuşmalar yapılmıştır. ${ }^{22}$ Aynı günlerde Macar elçisi Belá Andahazy’de Türkiye'ye gelerek, güven mektubunu Başbakan İnönü'ye takdim etmiştir. ${ }^{23}$

\section{Ekonomik ve Ticari İlişkiler}

II. Dünya Savaşı'na girmeyerek uzun vadede savaşın taraf ülkelerde yaratmış olduğu siyasi ve ekonomik yıkımlardan kendisini muaf tutmayı başaran Türkiye, yine de yaşanan felaketin etkilerini yakından hissetmiştir. Harbin başlaması ile Avrupa'nın içine düştüğü ekonomik bunalım, Türkiye'nin uluslararası ticaret ilişkilerinde, takas ve kliring uygulamalarını arttırmış ve dış ticaret kontrollerini en düzeye çıkartmıştır. Türkiye'nin kontrollü ve koruyucu bir

\footnotetext{
${ }^{18}$ Saral, a.g.t., s. 213 .

19 "Macaristan ve Türkiye", Cumhuriyet, 2.12.1945, s.4.

${ }^{20} B C A, 30.10 .0 .0,233.569 .21$, Dosya: 421/124.

21 “Ankara'da Macar Temsilcisi”, Cumhuriyet, 25.9.1946, s.3.

22 “Türk-Macar Dostluğu”,Cumhuriyet, 22.2.1947, s. 1.

23 "Macar Elçisi İtimadnamesini Takdim Etti", Cumhuriyet, 5.2.1947,s.3.
} 
sistem benimsemesi, iki ülke arasındaki ticari anlaşmaların kliring ${ }^{24}$ ve takas yolu ile gerçekleştirilmesine sebebiyet vermiştir. Savaşın tüm olumsuz koşullarına rağmen Türkiye ve Macaristan, siyasi ilişkilerini geliştirme arzusunun yanı sıra, ekonomik ve ticari ilişkilerini de geliştirmeye özen göstermiştir.

İki ülke arasındaki ticari ilişkiler özel teşebbüsleriyle devam etmiştir. Maliye Bakanlığı'nın 8 Mayıs 1939 tarihli yazısında, İzmir'de Rahmi, Kara Davut ve Buladur ticarethaneleri tarafından, orak ve harman makineleri için Macaristan'dan yedek malzeme alındı $\breve{g}_{1}^{25}, 11$ Mayıs 1939 tarihinde ise Macaristan'da deri ve kösele fabrikaları bulunan Macar Yahudisi SzegöVilmas ve fabrika müdürünün Türkiye'ye deri almak amacıyla incelemelerde bulunması için gerekli iznin verildiğ $i^{26}$ görülmektedir.

Yine 1939 yılında Ankara-İstanbul arasındaki telefon hattının düzenlenmesi ve konuşmaların çabuklaştırılması konusunda, Macaristan menşeli bir şirketin çalıştığı ve projede çıkan sorunların Şurayı Devlet üçüncü dairesine iletildiği görülmektedir. ${ }^{27}$

1940 yılında iki ülkenin ticaret erbabı arasında merkezi Ankara olan Türk-Macar Ticaret Limited Şirketi kurulmuştur. Kurulan bu şirketle Macar sanayi ve ticari kuruluşlarının Türkiye'de tanıtılmasını sağlayacak bir temsilcilik ve Türkiye'deki ticari kuruluşlarla ortaklıklar geliştirmek amaçlanmıştır. ${ }^{28}$

Türkiye ile Macaristan arasındaki ekonomik ve ticari ilişkilere, İkinci Dünya Savaşı yıllarında da önem verilmiştir. ${ }^{29} 26$ Nisan - 6 Mayıs 1940 tarihleri arasında Budapeşte'de düzenlenen Budapeşte Beynelmilel Panayırı'na Türkiye'de katılmıştır. ${ }^{30}$ Panayıra katılma kararına karşılık Ankara'daki Macaristan Elçisi Zoltan de Mariass, Hariciye vekili Saraçoğlu'na memnuniyetlerini bildirmiştir. ${ }^{31}$

1940 yılında, Adana, Afyon, Balıkesir, Bursa-Çekirge, İzmit, Kayseri, Konya, ZonguldakKozlu'da toplam 5500 abonelikle, 11 otomatik telefon santrali kurulması için Macar Standart Firması ile 23 Mart 1940 yılında sözleşme yapılmış, fakat Macaristan'ın içinde bulunduğu savaș koșulları nedeniyle sözleșme tamamen yerine getirilememiş, sadece 100 abonelik Adana santrali, 300 abonelik Afyon santrali, 1500 abonelik Bursa santrali, 500 abonelik İzmit santrali kurulmuş ve çalışır bir durumda idareye teslim edilmiştir. ${ }^{32}$

1940 yılında yapılan bir diğer anlaşma da, Macar Standart Elektrik anonim şirketi ile yapılmıştır. Ordunun ihtiyacını karşılamak üzere 100 telsiz cihazı, 1000 sahra telefonu ve 100

\footnotetext{
${ }^{24}$ Kliring (Clearing):Ülkeler arasında iki yanlı ticaret anlaşmalarının bir türü. Kliring anlaşmalı ülkeler arasında ithalat ve ihracat işlemleri döviz kullanılmadan, hesaba dâhil etme, takas yolu ile kliring ofisleri vasıtasıyla gerçekleştirilmesidir. Kliring kurumlar, merkez bankası ya da Kliring ofisidir. Okan Gümüş, Aziz Selvi; Uluslararası İlişkiler Sözlülüğ̈̈, Polat Yay. 1996,s.392.

${ }^{25} B C A, 30.10 .212 .441 .7$

${ }^{26} B C A, 30.18 .01 .02,86.40 .2$

${ }^{27} B C A, 30.10 .159,117.11$.

${ }^{28}$ Resmi Gazete, Say1:4556, 9.7.1940, s.14250-1252.

${ }^{29}$ Fethi Vecdet Erkun, Budapeşte'den Ankara'ya, Türk-Macar Dostluk Derneği Yayınları:2, Temmuz 1999, s.51-52.

${ }^{30} B C A, 30.18 .01 .02,90.40 .6,20.04 .1940$.

31 "Pește Fuarı Aç1ldı", Cumhuriyet, 27.4.1940, s.3.

32 Melek Çolak, "Cumhuriyet'in İlk Yıllarında Türkiye-Macaristan İktisadi İlişkileri”, Askeri Tarih Araştırmaları Dergisi, Genel Kurmay Askeri Tarih ve Stratejik Etüd Başkanlığı Yayınları, S. 4 Y. 2 A ğustos 2004, s.54.
} 
adet $15^{\prime}$ lik santral ödemesinin, Türk-Macar Kliring anlaşması ile $\% 50$ si ödenmiş, geriye kalan \%50'lik kısmının da \%90 ham bakır ile ödenmesi kararlaştırılmıştır. ${ }^{33}$

1941 yılında imzalanan anlaşma ile, Türk ordusunun ihtiyacı olan 600 adet manometre Macaristan'dan ithal edilmiş ve ödemesi kliring yoluyla yapılmışıır. ${ }^{34} 1941$ anlaşması ile yapılan diğer bir anlaşma da, Sümerbank ile Titaş'ın Macar Manfred Weiss ve Mavag firmalarıyla 1942 yılında gerçekleştirmiş olduğu takastır. Bu sözleşmeye göre Sümerbank, Macar Manfred Weiss firmasından 2.000 ton inşaat demiri ve 336.7 ton dikişsiz boruya karşılık, Türk menşeli olan 3571.9 ton döküm ve 4071.9 ton çelik blok; Titaş'in 1.000 ton beton demirine karş1lık 2.000 ton döküm ve fazla olarak 100 pengö ödenmiştir. ${ }^{35^{3}}$

24 Şubat 1943 tarihinde Budapeşte'de Türkiye ve Macaristan arasında Ticaret ve Tediye Antlaşması imzalanmıştır. ${ }^{36} \mathrm{Bu}$ anlaşma, 3 Mayıs 1941 tarihli Türk-Macar Anlaşması ile eklerinin yerine 22 Mart 1943 tarihinde yürürlüğe girmiştir. Bu anlaşmanın uzatılması için 14 Mart 1944 tarihinde Ankara'da bazı mektuplar teati olmuştur. ${ }^{37}$ Ardından 22 Mart 1944 tarihinde bitecek olan bu anlaşma, 31 Mayıs 1944 tarihine kadar uzatılmıştır. ${ }^{38}$

1943 y1lında imzalanan anlaşmaya göre, Macar Standart Elektrik Anonim şirketinden Türk Ordusu için 70 adet telsiz cihazı ile yedek malzemesi alınması kararlaştırılarak ödeme şekli olarak kliring esasları geçerli olmuştur. ${ }^{39} 8$ Eylül 1943 tarihli kararnamede Macaristan'dan 472 adet manometre alımına karar verilmiş ve ödeme şekli olarak kliring esasları geçerli olmuştur. $^{40}$

Miklós Kállay Hükümeti, ülkesindeki Alman baskısı üzerine, dış ticaretinin hatırı sayılır kısmını ciddi Alman memnuniyetsizliğine rağmen Türkiye, İsviçre, İsveç gibi tarafsız ülkelere yönlendirmiştir. ${ }^{41} 1943$ yılında düzenlenen İzmir Fuar'ına Macaristan'ın da katılımı bu bakımdan önemlidir. Fuar Gazinosu'nda Vali Sabri Öney'in, belediye ve parti reisleriyle matbuat erkânı şerefine verdiği ziyafetin sonunda, Macar Elçisi Vörnle bir nutuk söyleyerek Macaristan'ın fuara davet edilmiş olmasından dolayı teşekkürlerini iletmiş ve iki millet arasındaki münasebetlere temas ederek şöyle demiştir:

"İki milletin aynı besiye, aynı hayat zevkine malik ve her ikisinin de ömürleri boyunca bu kadar kan döktükleri hürriyete aynı aşkla bağlı oldukları nazarı itibara alınırsa bu mütekabil kardeşlik hissinde bir fevkaladelik görünmez. Her iki milletin karabeti üzerinde ısrar etmek istenirse lisana müracaat kâfidir. Türk dilinden alınan birçok Macarca kelimeler Türk medeniyetini Macar medeniyetini zenginleştirmiş olduğuna delalet eder. Bu kelimeler ispat eder ki Türk ziraat ve sanayinin muhtelif şubeleri ve aletleri Macarlar tarafindan imtisal

\footnotetext{
${ }^{33} B C A, 30.18 . .1 .2,93.112 . .5$, Dosya:46.

${ }^{34} B C A, 30.18 .01 .02,96.93 .07,15.10 .1941$.

${ }^{35}$ Resmi Gazete, 27.4.1942, Say1: 5093, s. 2756.

${ }^{36}$ Kanun No:4458, 7 Temmuz 1943; Resmi Gazete, 15 Temmuz 1943, 5456.

${ }^{37}$ Kanun No:4614, 10 Temmuz 1944; Resmi Gazete, 18 Temmuz 1944, 5759.

${ }^{38} B C A, 30.18 .01 .02,105.21 .16,20.03 .1944 ; B C A, 30.18 .01 .02,105.24 .8,13.04 .1944 ; B C A, 30.18 .01 .02$, $105.24 .19,30.03 .1944$.

${ }^{39} B C A, 30.18 .01 .02,102.57 .11,26.07 .1943 ; B C A, 30.10,52.343 .28,21.10 .1943$.

${ }^{40} B C A, 30.18 .01 .02,102.63 .8$.

${ }^{41}$ Saral, a.g.t., s.243.
} 
edilmiştir. Bu sergi Macarların Türk milletine borçlu olduğumuz her şeye alenen ve resmen teşekkür etmesi için bir firsattır. "42

24 Şubat 1943 tarihli ticari anlaşması ve tediyelerine ait anlaşmanın 22 Mart 1944 tarihinde son bulması üzerine, Dışişleri Bakanlığı Ticari ve Tali Anlaşmalar Müzakere Heyeti Başkanlığına Burhan Zihni Sanus getirilmiş ve anlaşma imza yetkisi kendisine verilerek, Sanus başkanlığında bir heyet oluşturulmuştur. Nisan-Mayıs ayları boyunca Ankara'da gerçekleşen Türk-Macar müzakerelerinde, 3 Mayıs 1944 tarihinde Türk-Macar Ticaret Anlaşması ve Ticaret anlaşmasına ek olarak Türk-Macar Tediye Anlaşması imzalanmıştır. Bu anlaşmaları Türk Hükümeti adına Sanus, Macar Hükümeti adına Vörnle imzalamıştır. ${ }^{43}$

Savaş sonrası dönemde de iki ülke ticaretini geliştirmek istemiştir. 21 Ekim 1946 tarihinde bir Macar ticaret heyeti Ankara'ya gelmiştir. Bu dönemde Macar Hükümeti de, Türkiye ile ticari ilişkilerini önemli surette geliştirme kararını vermiştir. Türkiye'ye gelen bu Macar heyet, ticari ilişkilerin geliştirilmesi için çalışmıştır. 1948 yılında Macar Standart firması tarafından Türkiye'de 11 şehirde otomatik telefon santralinin genişletilmesi ve 3000 tane otomatik telefon temini işinin bedeli, takas yoluyla yapılmıştır. ${ }^{44}$

Türkiye ile Macaristan arasında, 12 Mayıs 1949 tarihinde, Ankara'da Ticaret ve Tediye Antlaşmaları ve ekleri imzalanmıştır. Bu antlaşma, 21.12.1949 tarihinde 5469 kanun numarasıyla yürürlüğe girmiş ve iki ülke arasındaki ticari ilişkileri geliştirmek üzere ithal ve ihraç müsaadesi ve lisansları vermek için birbirlerine mümkün olduğunca kolaylık sağlamaları amacıyla imzalanmıştır. $\mathrm{Bu}$ amaçla ticari işleri kolaylaştırmak için kurulan karma bir komisyon, taraflardan birinin talebi üzerine toplanacak ve bu antlaşmanın uygulanmasını takip için Türkiye ile Macaristan arasındaki ticari ilişkileri iyileştirmek yolundaki her türlü teklifi, iki hükümete de arz etme yetkisine sahip olacaktı. Bir yıllığına imzalanan bu antlaşma, iki ay önceden haber verilerek feshedilmedikçe, birer yıllık süreler için kendiliğinden uzatılabilecekti. ${ }^{45}$

Bu dönemde Türkiye'nin Macaristan'a başlıca ihraç ürünlerini; küspe, kuru üzüm, keten, susam, tiftik, tütün, kuru üzüm, haşhaş, keten tohumu, ayçiçeği tohumu, kenevir tohumu, balmumu, kuru üzüm, döküm, çelik bloklar ve bakır oluşturmaktadır. Türkiye'nin Macaristan'a başlıca ithal ürünlerini ise; canlı hayvan, yangın söndürücü, telli veya telsiz telgraf ve telefon tesisatı ve bunların teknik asamı, buhar kazanı, ziraat makineleri, kopya ve yazı çoğaltma kâğıtları, kurşun-çinko halitaları ve her nevi demirden el aleti oluşturmaktadır. İki ülke arasında Ticaret ve Ödeme Anlaşmaları ile tespit edilen ithalat ve ihracat maddeleri genel olarak iki ülkenin ekonomik yapılarına uygun bir nitelik taşımıştır ve yıldan yıla önemli değişiklikler göstermemiştir.

\section{Kültürel ve Sosyal İlişskiler}

Tarihin eski dönemlerinden itibaren çeşitli ilişkiler içerisinde bulunan Türk ve Macar halkları, ortak kültür çevreleri, ortak kültür kökleri ve ortak kültür değerleri olan iki ulus olmuşlardır. Macaristan'daki yüz elli yıllık Osmanlı hâkimiyeti devri, Birinci Dünya Savaşı boyunca süregelen müttefiklik ve savaş sonrası ilişkilerin tekrar hızlıca tesis edilmesi ve

\footnotetext{
42“Macar Elçisi Fuarımızı Ziyaret Etti”, Ulus, 9.9.1943, s.2; “Macar Elçisi İzmir Fuarına Gitti”, Cumhuriyet, 6.9.1943, s.2; "Macar Elçisi İzmir'de”, Cumhuriyet, 7.9.1943, s.3; “ Macar Sefiri Fuarda Bir Ziyafet Verdi", Akşam, 8.9.1943, s.1.

${ }^{43} B C A, 30.18 .01 .02$, 105.41.4, Dosya:71-126; Kanun No:4661, 4 Eylül 1944; Resmi Gazete, 11 Eylül 1944, s.5805.

${ }^{44} B C A, 30.18 .01 .01,117.60 .20,15.09 .1948 ; B C A, 30.18 .01,115.90 .09,31.01 .1948$.

${ }^{45}$ Resmi Gazete, 28.12.1949, S. 7391, s.17431.
} 
özellikle de Cumhuriyet dönemi iki ülkenin ilişkilerinin dostane şekilde devamlılığ birlikte, İkinci Dünya Savaşı yılları ve sonrasında ilişkilerin problemsiz bir şekilde ilerletilmesini sağlamıştır. Macaristan'daki Türkoloji kürsüsü ve Cumhuriyet döneminde Ankara'da açılan Hungaroloji kürsüsü ikili kültür ilişkilerini perçinleyen iki önemli kilometre taş1 olmuştur. Savaş sırasınca ilişkiler umut vaad edecek şekilde ilerlemişse de, savaşın bitmesinin ardından, Macaristan'ın yavaş yavaş Doğu Bloku'nda yer almasıyla paralel ilişkiler zayıflamaya başlamıştır.

Savaşın şiddetli bir şekilde devam ettiği 1940’ta Cumhurbaşkanı İnönü, Ankara Üniversitesi Hungaroloji bölümünü ziyaret etmiş, "Macarlarl ve Macar kültürünü tetkik etmek alaka vericidir. Yabancı bir muhitte Macarların kendilerini ve kültürlerini muhafaza edebilmeleri dikkate şayandır" sözleriyle Macar milletiyle olan ilişkilerimize verdiği önemi göstermiştir. ${ }^{46}$

Bilimsel çalışmalar, ikinci Dünya Savaşı sırasında da devam etmiştir. Örneğin, Macar arkeolog Géza Fehér (1890-1955), 1944 senesinde Türkiye’ye gelerek tetkiklerde bulunmuş ve bu konuda Macar hükümetine bir rapor sunmuştur. ${ }^{47} 1939$ yılında İstanbul Üniversitesi Edebiyat Fakültesi, Türk Dili Profesörü Rahmeti Arat Macaristan'a gönderilen Türk uzmanlardandır. ${ }^{48}$ Hungaroloji kürsüsünün yetiştirmiş olduğu ilk öğrenciler arasında yer alan Şerif Mekki Baştav, 1942 yılında gittiği Macaristan'da doktora çalışması yürütmüştür. Eğitimi boyunca Nemeth, Fekete, Ligeti gibi hem Macaristan'ın hem de dünyanın ünlü Türkolog ve tarihçilerinden dersler almıştır. 1948 yılında Türkiye'ye dönmüş, 1951 yılında askere gidene kadar Hungaroloji kürsüsünde dersler vermiştir. ${ }^{49}$ Türk-Macar ilişkilerinde önemli Türk bilim adamlarından biri olan Hasan Eren, doktora öğrenimi için Macaristan'a gitmiş, 1944 yılında Budapeşte Üniversitesi, Türkoloji, Mongolostik ve Macar Filolojisi alanlarında doktorasını tamamlamıştır. ${ }^{50}$

Savaş boyunca ilişkilerin sorunsuz bir şekilde ilerlediğini, iki ülke arasında dostane ilişkilerin devam ettiğini yukarıda belirtmiştik. Buna bir örnekte 1943 yılında Tokat Erbaa'da meydana gelen deprem vesilesiyle görülmektedir. ${ }^{51}$ Savaşın tüm hızıyla devam ettiği bu dönemde yaşanan depremde, Macar basını Türkiye'nin başına gelen bu felakete duyduğu üzüntüye yer vermiş ve bu vesileyle Türk-Macar ilişkilerinin kardeşlik ve dostluk bağları üzerine kurulu olduğundan bahsettikleri gibi, Atatürk ve Kurtuluş Savaşı ve Cumhuriyet'ten de övgü ve hayranlıkla bahsetmişlerdir. ${ }^{52}$

Macaristan'a gönderilen Türk elçiler, görevleri süresince siyasi ilişkilerinin yanı sıra sosyal ilişkilere de ağırlık verdikleri gibi, Türk-Macar ilişkilerinde aktif bir rol üstlenmişlerdir. Ruşen Eşref Ünaydın'ın (1939-1943) Macaristan'da samimi dostluklar kurduğu, çeşitli vesilelerle etkinliklere katılarak Türkiye, Türk edebiyatı ve Türk-Macar ilişkileri ile ilgili konuşmalar yaptığı bilinmektedir. 10 Ocak 1941 tarihinde katıldı ̆̆ı, Macaristan Turan Cemiyeti’nin Genel

\footnotetext{
${ }^{46}$ László Rásonyi, Macarlar ve Türkler, Macar Balkan Encümeni Yayımı, Budapeşte, 1944, s.26.

${ }^{47}$ Saral, s. 416; N. Szabó József, "Magyar-Török Kulturális Kapcsolatok A Második Világháborút Követően”, Világtörténet, 2004. Tavasz-Nyár. s. 58.

${ }^{48} B C A, 30.18 .01 .02,88.79 .9,05.08 .1939$.

49 Ayşe D. Kuşçu, "Prof. Dr. Mekki Şerif Baştav”, Türk Yurdu, Aralık 2010, C. 30, S. 280, s. 72-74.

${ }^{50}$ Hasan Eren, Türk Dil Kurumu'ndan Eski Anılar, TDK yayınları, Ankara 2008, s.39.

51 Erbaa Depremi hakkında bkz: İsmet Üzen, “ 1942 ve 1943 Erbaa Depremleri”, Karadeniz Araştırmalart, S. 20, Kış 2014, s.77-93.

52 “ Macar Basını Acımızı Paylaşıyor”, Ulus, 1.1.1943, s.4; “Erbaa Zelzelesi Macaristan’da Büyük Teessür Uyandırdı”, Akşam, 1.1.1943, s.2; “Zelzele Dolayısıyla Bir Macar Gazetesi Taziyede Bulunuyor", Vakit, 1.1.1943, s.4.
} 
Kurulu'nda, Ruşen Eşref ile Macar-Türk öğrencilerinin değişiminin yeniden başlamasıyla ilgili bir anlaşmaya varılmış, fakat savaş şartları nedeniyle bu proje gerçekleştirilememiştir. ${ }^{53}$ Ayrıca Ruşen Eşref Ünaydın'ın Budapeşte'deki görevi sırasında Macar şairi İstván Vasile yayınlanmamış bir antoloji hazırlamıştır. ${ }^{54}$

İkinci Dünya Savaşı yıllarında, 1943'te, Budapeşte'de açılan Macar-Türk Dostluk Cemiyeti, iki ülkenin kültürel ilişkilerinde yeni bir köprü olmuştur. Cemiyet açılışına, Macar Turan Cemiyeti'nin üyelerinden de katılım olmuş, cemiyetin başkanlığına Mihaly Andrassy getirilmiştir. ${ }^{55}$ Cemiyetin idare heyeti toplantısında, Türkiye Cumhurbaşkanı, Başbakanı, Dışişleri ve Maarif Bakanları tarafından cemiyet başkanı Kont Andrassy'ye gönderilen tebrik ve temenni telgraflarının da okunmasına yer verilmiştir. ${ }^{56}$ Cemiyetin ilk toplantısında Ruşen Eşref Ünaydın'da yer almış, hatta bir de Türk Edebiyatı ile ilgili sunum yapmıştır. ${ }^{57}$

Macar-Türk Cemiyeti kurulduktan sonra, Türkiye Cumhuriyeti'nin 20nci yıldönümü nedeni ile, 1943 y1lında, Budapeşte'de Macar-Türk kardeşliği/dostluğunun bir göstergesi olarak, Turan Cemiyeti ve Macar Turan cemiyeti ile birlikte Gellert Oteli'nde, Türkiye Budapeşte Elçisi Şevket Fuat Keçeci ve diğer elçilik mensuplarının da katıldığ 400 kişilik bir resepsiyon düzenlenmiştir. ${ }^{58}$

Macar basınında 29 Ekim Cumhuriyet Bayramı kutlamaları hakkında birçok yazı yayınlanmıştır. Bunlardan biri de Pester Llyod gazetesindeki şu haberdir;

\begin{abstract}
"Türkiye Cumhuriyeti insaniyetin maruz felaketler devresinde bütün milletler tarafindan yalnız hürmet edilmekle kalmayarak, ciddi bir kuvvet amili olarak itibara alınıyorsa, bunu Türkiye Devletinin sevk ve idaresine medyundur. Türkiye'nin devlet adamlarının kiyaset ve uzak görüşlülüğüne, şimdiye kadarki muvazene siyasetine devam edeceğine bütün dünya kanidir. Macar Milleti Türkiye’ye karşı çok zamandan beri samimi dostluk hisleri ile bă̆lıdır." 59
\end{abstract}

Bu haberlerden de anlaşılacağı üzere Türk-Macar dostluğunun her zaman devam ettiği ve sürdürülmesi istendiğini göstermektedir.

1944 senesinde, Macaristan'ın fiilen Almanya tarafından işgal edilmesi ile, devlet başkanı Miklos Horty, İkinci Dünya Savaşı hakkındaki tutumu hasebiyle istifaya zorlanmış, sonrasında Hitler yanlısı Döme Sztójay Macaristan başkanı olarak başa getirilmiştir. ${ }^{60}$ Sonrasında Macaristan'da Almanya sefiri yerine Büyük Alman İmparatorluğu komiseri yetkilendirilmiş ve bunun ardından 440.000 Macar Yahudisi toplama kamplarına gönderilmiştir. ${ }^{61}$ Dönemde Budapeşte'de görevli elçi Pertev Şevki Kantemir (1939-1944) ve Kantemir'den sonraki Konsolos Abdülahat Birden (1942-1944) Macar Yahudilerine yardım eli uzatan isimler

\footnotetext{
${ }^{53}$ Nizam Önen, İki Turan Macaristan ve Türkiye 'de Turancılık, İletişim Yayınları, İstanbul, 2005, s.244.

${ }^{54}$ Mária Nyíri,“Oldukça Uzak Geçmişten Başlayarak 1996’ya Kadar Tarih Boyunca Türk-Macar İlişkilerine Kısa Bir Bakış”, Türk Dünyası Araştırmaları, S. 149, Nisan 2004, s. 220.

${ }^{55}$ Önen, age, s.244.

${ }^{56}$ Yücel Namal Türk Kaynakları Işı̆̆ıında Türk-Macar İlişkileri(1923-1950), Yayımlanmış Doktora Tezi, Ankara Üniversitesi, Ankara 2013, s.202.

57،"Peşte Elçimiz Geliyor” Cumhuriyet, 4.8.1943, s.3.

58 "Parlak Törenler", Cumhuriyet, 31.10.1943, s.1.

59 "Macaristan'da", Cumhuriyet, 30.10.1943, s.3.

${ }^{60}$ Miklós Molnár, A Concise History of Hungary, (Translatedby Anna Magyar), Cambridge University Press, Sixth Printing, Cambridge 2009, s. 291

${ }^{61}$ Melek Çolak, "II. Dünya Savaşı Yıllarında Macar Yahudileri ve Türkiye”, Karadeniz Araştırmaları, S. 27, Güz, 2010, s.84.
}

\title{
History Studies
}


olmuştur. $^{62}$ Budapeşte Türk Elçiliği, sığınma talep eden Macar Musevi aileleri için Türkiye Cumhuriyeti pasaportu düzenleyerek, Türkiye üzerinden Filistin ya da Amerika'ya gitmelerini sağlamıştır. ${ }^{63}$

Pasaport düzenlenmesi dışında Türk Hükümeti, isteyen Macar Yahudilerinin Türkiye'ye gitmesine yardım etmiş ve çalıșma izni ile çeșitli kurumlarda ișe yerleștirerek geçimlerini sağlamalarına olanak vermiştir. Talep edenlerin oturma ve çalışma izinleri de uzatılmıştır. Macar Yahudileriyle evlenen Türklere de kolaylık sağlanmış, bu aileler için de girişimlerde bulunulmuştur. Bu ailelerden biri de müzikolog Adnan Saygun'un eşi Iren Szalay'ın ailesidir. ${ }^{64}$

Türkiye, İkinci Dünya Savaşı süresince, Alman ve Rus ordularının verdiği zarar sebebiyle zor günler geçiren kadim dostu Macaristan'a yardım eli uzatmaktan geri durmamıştır. ${ }^{65}$ Yıpratıcı dönemde birbirlerini yalnız bırakmayarak destek olan bu iki milletin ekmeğini de birbirleriyle paylaştığını ifade edilmesi de yanlış olmayacaktır. Macaristan'da Macar Dostu olarak bilinen eski Macaristan Elçisi Enis Behiç Erkin'in önderliğinde başlatılan yardım kampanyasıyla $^{66}$, Kızılay'ın organizatörlügüunde, bütün şehirlerde organize bir şekilde yardımların toplanması kararlaştırılmıştır. ${ }^{67}$ İlk olarak Kızılay İzmir'den vapurla altmış ton buğday, Çocuk Esirgeme Kurumu' da sekin bin kilo üzüm ve altı bin kilo incir göndermiştir. ${ }^{68}$ Macaristan Devlet arşivinde bulunan belgede, Türk Kızılayı'ndan Macar Kızılhaçı'na gönderilen yardımlar ilgili hazırlanan raporda ise verilen rakamlar şöyledir; 23 Aralık 1946 tarihinde "Tisza" isimli geminin Macar Kızılhaçı'na teslim ettikleri; 19.766 kg şeker, $4.769 \mathrm{~kg}$ kuru üzüm, $3.581 \mathrm{~kg}$ yağ, $1.197 \mathrm{~kg}$ süt tozu, $927 \mathrm{~kg}$ sabun ve $552 \mathrm{~kg}$ keten bezi olarak geçmektedir. ${ }^{69}$

Bir diğer yardım gönderen de İzmir Ticaret Odası vasıtasıyla, İzmir halkı olmuştur. Budapeşte Ticaret Odası'nın, İzmir Ticaret Odası'na ülkenin içinde bulunduğu durumu bildirmesi üzerine, İzmir halkının toplamış olduğu gıda yardımı Budapeşte'ye gönderilmiştir. ${ }^{70}$ 1946 yılı boyunca Türkiye'den, Macaristan'a yardımlar devam etmiştir. ${ }^{71}$

Macaristan'daki gıda sıkıntısına yardım eli uzatan bir diğer kurum da Ankara Üniversitesi olmuştur. Dönemin Hungaroloji kürsüsü çalışanlarından Prof. Dr. Tibor Halasi Kun'un önderliğinde başlatılan yardım kampanyasında, geliri Macaristan'a bağışlanacak gösteriler

${ }_{62}^{62}$ Erkun, s.92; Antal, agm, s.8

${ }^{63}$ Nyiri, s. 220

${ }^{64}$ Agm, .s.221.

${ }^{65}$ N.F Dreisziger, "The Second World Warandits Aftermath”, Hungarian Studies Review, Vol:XXVIII, Nos.1-2, Spring-Fall 2001,41-45;"Macaristan'da Açlık”, Akşam, 9.1.1946, s.2; "Macaristan'da Kitlık", Tanin, 3.1.1946; "Budapeşte'de Açlık”, Vakit, 3.1.1946, s.2; “ Times'in Peşte Muhabiri Milyonlarca Macar'ın Açlık Tehdidi Altında Olduğunu Yazıyor,”, Ulus, 7.4.1946, s.3.

${ }^{66}$ Asım Us, “ Türk-Macar Kardeşlik Duygusu”, Vakit, 1.4.1946, s.1-s.4.

67 "Kızılayın Macar Fakirlerine Yardımı”, Cumhuriyet, 19.1.1946, s.1; "Macaristana Yapacağımız Yardım”, Cumhuriyet, 20.2.1946, s.1.

68 "Macaristana Yardim", Cumhuriyet, 24.2.1946, s.1.

${ }^{69}$ Magyar Nemzeti Levéltár Országos Levéltár ( MNL) OL P 1001, 20.tetel No:12’den aktaran, Arşiv Belgelerine Göre Osmanlı'dan Günümüze Türk-Macar Iliş̧kileri, Başbakanlık Devlet Arşivleri Genel Müdürlüğü, İstanbul 2016, s.480.

70 "Peşte Ticaret Odası Memurlarına Yardım", Cumhuriyet, 27.3.1946, s.3.

71 "Macarlara Yardım”, Cumhuriyet, 12.4.1946, s.1-2; “ Macaristan'a Yardım Hakkında Bir Açıklama”, Ulus, 3.5.1946, s.2; “"Macarlara Türk Yardımı”, Ulus, 11.4.1946, s.2 
düzenlenmiştir. ${ }^{72}$ Ülke genelinde sürdürülen yardım kampanyasına, dönemin Cumhurbaşkanı İsmet İnönü de 20.000 liralık bağışta bulunmuştur. ${ }^{73}$

$\mathrm{Bu}$ hususlar dışında bahsedilmesi gereken başka önemli bir konu edebiyattır. Türkiye ve Macaristan edebiyatçılarının, kadim ilişkilerinin serüvenine paralel olarak birikimlerinin politik, tarihi ve kültürel bağlarla, iki ülkenin edebi yazınında da bir etkileșim içine girdikleri ve bunu kalemlerine yansıttıkları görülmüştür. $\mathrm{Bu}$ etkileşim sarmalına rağmen, Türk edebiyatının Macaristan'daki çeviri süreci çok eskilere dayanmakta iken, Macar edebiyatının Türkiye'de sistemli bir şekilde yayınlanmaya başlaması çok daha sonradan olmuştur. Behçet Necatigil'in belirttiğine göre Macar edebiyatından ilk çeviri kitabı, 1940'ta yayımlanan İ. Lazar'ın Vesta Rahibesi (çev: Necmi Seren) isimli romandır. ${ }^{74}$ Vesta Rahibesi Ahmet Halit Kitabevi'nin “Şarktan Garptan Tercüme Eserler" dizisindeki ilk Macar romanıdır. Macar halk yazarlarından olan Lazar'ın bu eseri doğrudan doğruya Macarca'dan çevrilmiştir.

Dönemin Milli Eğitim Bakanı Hasan Ali Yücel'in başlatmış olduğu, Dünya Edebiyatından Tercümeler dizisinde Macar Klasiklerinin ilk kitabı olan Kelemen Mikes'in yazmış olduğu Türkiye Mektupları isimli eser, Sadrettin Karatay tarafindan çevrilerek iki cilt halinde 1944-45 yıllarında yayımlanmıştır. Türk-Macar tarihinin ve dostluğunun bir simgesi olan Türkiye Mektuplarının yayımlanan ilk kitap olması dikkat çekicidir. Mikes'in ilk kitap olarak seçilmesinde, dönemin A.Ü Hungaroloji Bölümü’nde bulunan Prof. Dr. Tibor Halasi-Kun'un yönetiminde çevrilmesinin de etkisi olmuştur. ${ }^{75}$

$\mathrm{Bu}$ dönemde gelen Macar uzmanların kültürel ve sosyal alanlarda Türkiye'ye önemli katkıları olmuştur. Bir sonraki bölümde detaylı şekilde verilen uzmanlardan, kültürel alanlarda çalışmalarda bulunanlara örnekler ise şöyledir; 1938 yılında Türkiye'ye ikinci kez gelen Macar keman virtüözü Lico Amar, Ankara Devlet Konservatuarı'na Keman Profesörü ve Yaylı Çalgılar Bölüm Başkanı olarak atanmış ve 1957 yılına kadar tam yirmi yıl boyunca bu görevde çalışmıştır. Amar, Türkiye'de, çağdaş müziği tanıtan birden fazla konser vermiştir. Türkiye'de keman öğretiminde önemli rol oynayan Amar, Suna Kan, Oktay Dalaysel, Ulvi Yücelen, Erdoğan Kürkçü, Orhan Kadam, Münir Akman, Gülden Turalı, Ömer Can, Cengiz Özkök gibi birçok önemli keman sanatçısı ve keman eğitimcisi yetiştirmiştir. ${ }^{76}$

Savaşın başladığı 1939 yılında, Eskişehir Hava Okulu'nun kalorifer bölümünde 3 uzman $^{77}$ ve yine okulun hangar inşaat kadraj kalorifer ve sıhhi tesisat işlerinde 5 uzman $^{78}$, Devlet Orman İşletmesi'nde Biro isimli bir mühendis ${ }^{79}$, Muş’ta şehir elektirik tesisatında Aleksandır

\footnotetext{
72 “Üniversiteliler Tarafından Macar Gençlerine Yardım”, Ulus, 5.5.1946, s.1; Erdal Çoban, “ Türkiye'de Bir Macar Türkolog: Tibor Halasi-Kun”, DTCF Dergisi, C. 56, S. 2, s.426.

${ }^{73}$ Agm, s.426.

${ }^{74}$ Behçet Necatigil, “ Balkan Ülkeleri Edebiyatlarından Türkçeye Çeviriler”, Türk Dili, Çeviri Sorunları Özel Sayısı, 1 Temmuz 1978, Sayı:322, s.133.

75 Sami N. Özerdim, “ Macar Yazınından Çeviriler”, A.Ü Siyasal Bilgiler Fakültesi Basın ve Yayın Yüksek Okulu Yıllık 1979-1980, S.B.F. Basın ve Yayın Yüksek Okulu Basımevi, Ankara 1981, s.248; József, a.g.m, s. 54-55.

${ }^{76}$ Zafer Kurtaslan, “ Türk Keman Okulunun Oluşum Süreci ve Temsilcileri”, Türkiyat Araştırmaları Dergisi, S. 26, Güz 2009, s. 419-420; Ali Uçan, “ Türk- Macar Kültür/Müzik İlişkilerine ve Türk-Macar Karş1laştırmalı Halk Müziği Araştırmalarına Bir Bakış”, Türk-Macar Halk Müziğinin Karşılaştırmalı Araştırması, Macaristan Cumhuriyeti Ankara Büyükelçiliği Yayını, Ankara 2005, s.58.

${ }^{77} B C A, 30.18 .1 .2,87.62 .20$, Dosya: 241-148.

${ }^{78} B C A, 30.18 .1 .2,87.55 .7$, Dosya: 241-172.

${ }^{79} B C A, 30.18 .1 .2,87.50 .1$, Dosya: 243-407.
} 
$\mathrm{Cupar}^{80}$, Sivas çimento fabrikasında Ladislas Szabo ${ }^{81}$, Zonguldak Çatalağzı Santrali'nin yapılmasında betoncu Antal ${ }^{82}$, Karadeniz Ereğlisi maden işletmesinde Aurel Stausz ${ }^{83}$, Ankara Bira Fabrikası'nda malt ustası olarak Mihael Hirseh ${ }^{84}$, İzmir Belediye Un Fabrikası'nda Mihal oğlu Geork ${ }^{85}$ istihdam edilmiştir.

1940 yılında İzmit Selülöz Fabrikası'nda 2 montör $^{86}$, Ergani bakır madeninde Armanda Mautner isimli bir işçi ${ }^{87}$, yine Ergani bakır madeninde izbahane bacasında Augustin Kiss ${ }^{88}$, Mersin vinç montöründe Ladislas Förtner ${ }^{89}$, Seyhan sulama kanalının sifon ve köprü inşaatında Beck Boldizsar ${ }^{90}$ istihdam edilen uzmanlardır. 1941 yılında Ereğli Kömür İşletmesi'nde Frans Dubek isimli bir uzman ${ }^{91}$, İzmit-Sapanca su isalesi tulumba montajında 4 uzman $^{92}$, Etibank'da Georges Neuman isimli bir elektirik mühendisi ${ }^{93}$, Alat-1 Ziraiye Farikası'nda Mihali Bordç ve Josef Fuszek ${ }^{94}$ istihdam edilmiştir. Bu dönemde Devlet Demiryolları'nda da Macar uzmanların katkıları devam etmiş, 1942 yılında Gyorgy Borot isimli bir uzman ${ }^{95}$ ve Devlet Demiryolları'nın yeni bina ve tesislerinin dekorasyon işleri için Istvan Bernhard ${ }^{96}$ istihdam edilmiştir. Yine aynı yıl, Türkiye Kömür Satış Müessesi Mahrukat Mühendisliği'nde Ladislas Komor isimli bir mühendis ${ }^{97}$, telefon santralleri için Laszlo Vargo isimli bir mühendis ile Jozef Vereb isimli bir montör ${ }^{98}$ istihdam edilmiştir.

İzmit Selülöz Fabrikası'nda Faranç Tömpe ${ }^{99}$, Türkiye Demir-Çelik Fabrikaları'na bağlı Asit Sülfürik Fabrikası'nda Baki Viktor ${ }^{100}$, Umumi Mağazalar TAŞ'da Antol Lüthmetzer ${ }^{101}$, PTT Umum Müdürlüğü'nde Tibor Nadas ${ }^{102}$, telefon santrallerinin montajı için Josef Belovari ve Josef Buclavori ${ }^{103}$ ve iki kadın montör ${ }^{104}$, Sümerbank'da Marton Tımar isimli bir uzman ${ }^{105}$, Etimesgut uçak fabrikasında Mihli Morton ${ }^{106}$, İzmit 2. Kağıt Fabrikası'nda Etienne Erdös ${ }^{107}$,

HISTORY

STUDIES

183

Volume 12

Issue 1

February

2020

${ }^{80} B C A, 30.18 .1 .2,88.75 .14$, Dosya:243-439.

${ }^{81} B C A, 30.18 .1 .2,89.113 .2$, Dosya:243-467.

${ }^{82} B C A, 30.18 .1 .2,91.67 .1$.

${ }^{83} B C A, 30.18 .1 .2,89.119 .7$, Dosya:243-479.

${ }^{84} B C A, 30.18 .1 .2,89.120 .20, \quad$ Say1:2/12560,23.12.1939; $\quad B C A, \quad 30.18 .1 .2, \quad 93.124 .4, \quad$ Say1:2/15029, Dosya:243, 13.01.1941; $B C A, 30.18 .1 .2$ 97.119.14, Say1:2/17367.

${ }^{85} B C A, 30.18 .1 .2,86.23 .5$, Say1:2/10591, Dosya:1-940, 14.03.1939.

${ }^{86} B C A, 30.18 .1 .2,91.43 .15$, Dosya:243-525.

${ }^{87} B C A, 30.18 .1 .2,92.75 .15$, Dosya: 243-540.

${ }^{88} B C A, 30.18 .1 .2,90.14 .15$, Dosya:243-498. .

${ }^{89} B C A, 30.18 .1 .2,90.14 .15$, Dosya:143-479.

${ }^{90} B C A, 30.18 .1 .2,89.125 .5$, Dosya:143-479.

${ }^{91} B C A, 30.18 .1 .2,94.18 .8$, Dosya:243-568.

${ }^{92} B C A, 30.18 .1 .2,95.60 .20$, Dosya: 243-580.

${ }^{93} B C A, 30.18 .1 .2,96.76 .5$.

${ }^{94} B C A, 30.18 .1 .2,96.75,3$.

${ }^{95} B C A, 30.18 .1 .2,98.32 .13$.

${ }^{96} B C A, 30.18 .1 .2,98,41,15$.

${ }^{97} B C A, 30.18 .1 .2,298.40 .18$.

${ }^{98} B C A, 30.18 .1 .2,100.102 .11$.

${ }^{99} B C A, 30.18 .1 .2,102.53 .18$.

${ }^{100} B C A, 30.18 .1 .2,100.109 .13$, Dosya:243-652.

${ }^{101} B C A, 30.18 .1 .2,101.25 .5$, Dosya:164-62.

${ }^{102} B C A, 30.18 .1 .2,102.41 .7$.

${ }^{103} B C A, 30.18 .1 .2,102.41 .8$.

${ }^{104} B C A, 30.18 .1 .2,104.3 .12$.

${ }^{105} B C A, 30.18 .1 .2,102.54 .6$.

${ }^{106} B C A, 30.18 .1 .2,103.67 .20$, Dosya:63-162.

${ }^{107} B C A, 30.18 .1 .2,103.74 .19$. 
Devlet Konservatuarı'nda Jena Heinzelman isimli bir dans öğretmeni de ${ }^{108} 1943$ yılında istihdam edilmiştir.

MTA'da 1944 yılında iki profesör ${ }^{109}$ ve Ziraat Aletleri Fabrikası'nda Mihaly Bordos ${ }^{110}$ ve Jozef Fuszek ${ }^{111}$ istihdam edilmiş, 1945 yılında ise, Etibank işletmesinde Andre Retti ${ }^{112}$, Türkiye'nin ilk çay fabrikası olan Rize Çay Fabrikası'nda Bela Szabo mühendis olarak çalışmış $^{113}$, Gyorgy Biro'da Zirai Kombinalar Dairesi'nde ${ }^{114}$, Wagh Bertalan isimli bir yapı uzmanı Zirai Kombinalar Dairesi Devlet Çiftlikleri Yapı işlerinde ${ }^{115}$ istihdam edilmiştir.

Türkiye Zirai Donatım Kurumu'nda Mihaly Bordoş ve Jozef Fuzsek isimli iki uzman ${ }^{116}$, PTT Genel Müdürlüğü'nde Paul Braun De Belatini ${ }^{117}$ ve Joseph Belavori ${ }^{118}$ isimli iki uzman 1946 yılında istihdam edilmiştir. 1947 yılında Şose ve Köprüler Reisliği Fen Kurulu'nda Etienne Bartos ve Nikolas Hein ${ }^{119}$, Türkiye Zirai Donatım Kurumu'nda Janos György ${ }^{120} 1948$ yılında ise Orman Genel Müdürlüğü'nde Paul Farkas isimli bir yüksek mühendis ${ }^{121}$, Alpullu Şeker Fabrikası'nda ise Solymossey Aladar ${ }^{122}$ isimli uzman istihdam edilmiştir. PTT Genel Müdürlüğ̈̈’nde Offer Bella isimli bir uzman 1950 yılında ${ }^{123}$ istihdam edilmiştir.

Türkiye'ye gelen Macar uzmanlardan biri de, futbol uzmanı Ignáce Molnár'dır. Ignáce Molnár Türkiye'ye 1947 yılında gelmiş, Fenerbahçe Spor Kulübü'nde üç dönem teknik direktörlük yapmıştır. Molnár'ın çalıştığı ilk dönemde, 1947-1948 sezonunda, Fenarbahçe sadece tek beraberlikle, 14 maçta 41 puan alarak şampiyon olmuştur. Ignáce Molnár, bu başarısı sonucunda 23 Nisan 1948 yılında Türkiye Milli Futbol Takımı'nın başına getirilmiştir. Ayrıca Türkiye 1948 Londra Olimpiyatları'na Ignáce Molnár ile katılmıştır. ${ }^{124}$

Macar bilim insanları da bu dönemde Türkiye’ye gelmiștir. Ünlü Macar hücre biyologu ve dokubilimci Prof. Tibor Péterfi (1883-1953), 1939-1946 yılları arasında İstanbul Tıp Fakültesi Histoloji ve Embriyoloji kürsüsünde görev yapmıştır. 1 Ağustos 1941 tarihinden itibaren bu kürsünün başına geçen Péterfi, mikroskop altında küçük canlı objeler ile hücrede operasyon yapabilme imkânını sağlayan mikromanipulator isimli aygıtın kâşifi ve mikrurji kavramının

${ }^{108} B C A, 30.18 .1 .2,101.7 .11$, Dosya: 242-295.

${ }^{109} B C A, 30.18 .1 .2,105.38 .3$, Dosya: 27-77.

${ }^{110} B C A$, 30.18.1.2, 98.34.18, Say1:177912; BCA, 30.18.1.2, 108.42.3, Say1:3/2810, Dosya:2771, 02.07.1945.

${ }^{111} B C A$, 30.18.1.2, 98.34.18, Say1:177912; BCA, 30.18.1.2, 108.42.3, Say1:3/2810, Dosya:2771, 02.07.1945; $B C A, 30.18 .1 .2,110.20 .20$, Say1:3/3911, 18.03.1946.

${ }^{112} B C A, 30.18 .1 .2,107.98 .1$, Dosya:2742.

${ }^{113} B C A, 30.18 .1 .2,109.66 .15$, Dosya:27216.

${ }^{114} B C A, 30.18 .1 .2,109.66 .16$, Dosya: 27220 .

${ }^{115} B C A, 30.18 .1 .2,109.66 .14$, Say1: 3/3301, Dosya:27219, 12.11.1945.

${ }^{116} B C A, 30.18 .1 .2,110.20 .20$.

${ }^{117} B C A, 30.18 .1 .2,110.22 .10$.

${ }^{118} B C A, 30.18 .1 .2,11.34 .13$, Dosya: 27-298.

${ }^{119} B C A, 30.18 .1 .2,113.22 .12$, Dosya:27-321.

${ }^{120} B C A, 30.18 .1 .2,115.70 .12$, Dosya:27216, Say1:33023, 12.11.1945.

${ }^{121} B C A, 30.18 .1 .2,116.22 .1$, Dosya:27-329.

${ }^{122} B C A, 30.18 .1 .2,112.91 .13$, Say1:3/5312, Dosya:27-34, 30.01.1947.

${ }^{123} B C A, 30.18 .1 .2,195.28 .15$, Dosya: 27-86.

${ }^{124}$ Seyfi Yıldırım, "Cumhuriyet Döneminde Türk-Macar İlişkileri Çerçevesinde İstihdam Edilen Macar Uzmanlar”, Cumhuriyet Tarihi Araştırmaları Dergisi, Y. 8, S. 15, Bahar 2012, s.137; BCA, 30.18.1.2, 116.35.13Dosya: 27-393. 
kurucusu, dünyaca ünlü bir bilim adamıdır. Yapmış olduğu çalışmalarla kürsünün ilk araştırma yayımlarını başlatmıştır. ${ }^{125}$

1945 yılında Türkiye'de çalışan bir diğer uzman da Dr. János Eckmann'dır. Ankara Üniversitesi Dil ve Tarih Coğrafya Fakültesi Hungaroloji bölümünde, Macarca okutmanı olarak 1948 yılına kadar görevine devam etmiştir ${ }^{126}$. Hungaroloji bölümündeki görevinin sona ermesinden sonra ise, 1948-1951 yıllarında Türk Ansiklopedisi'nde yazı kurulu üyesi olarak görev almış ${ }^{127}$, bu görevinin bitiminden sonra da İstanbul Üniversitesi Edebiyat Bölümü’nde ${ }^{128}$ okutman olarak görevini sürdürmüştür.

Bir diğer bilim insanı da Türkolog Tibor Halasi-Kun olmuştur. 1943-1948 yılları arasında Ankara DTCF Hungaroloji bölümünde, o zamanki adıyla Hungaroloji Enstitüsü'nde görev almıştır. Halasi-Kun, Ankara'da, Macar bilimsel ve edebi eserlerin Türkçeye çevrilmesi çalışmalarına katılmış, ayrıca İstanbul belgeliklerinde bulunan defterlerin yayımlanması ve değerlendirilmesi ile ilgili çalışmalarda bulunmuştur. ${ }^{129}$ Halasi-Kun Türkiye'deki yıllarında sadece bilimsel faaliyetlerde bulunmamış, Türk-Macar ilişkilerinin geliştirilmesine de katkı sağlamıştır.

Gyula Mészáros bir başka Türkolog ve aynı zamanda etnograftır. Daha önceleri de Türkiye'de bulunmuş olan Mészáros, aynı zamanda Ankara Etnografya Müzesi'nin kurucusudur. Gyula Mészáros 1946-1950 yılları arasında İstanbul Üniversitesi Edebiyat Fakültesi Etnoloji Kürsüsü'nde görev almıştır. ${ }^{130}$ Üniversitelerde istihdam edilen bir diğer uzman da, 1947 y1lında İstanbul Teknik Üniversitesi Elektrik Fakültesi'nde Telgraf ve Telefon dersi okutmanı olarak çalıştırılan Paul Braun de Beletini'dir. ${ }^{131}$

Türkiye'de çalışması için 2 yıl boyunca mücadele edilen bir diğer bilim insanı da Prof. Dr.

Volume 12

Issue 1

February 2020

Ernö de Balogh olmuştur. Prof. Balogh Budapeşte Üniversitesi Tıp Fakültesi Dekanlığı yapmış ve Patolojik Anatomi Enstitüsü Direktörü, Deneysel Kanser Esntitüsü kurucusu, Macar Kraliyet Bilimler Akademisi üyesi, Macar Patologlar Cemiyeti gibi birçok alanda görev almış, başarılı bir bilim insanıdır. 1947 yılında İstanbul Üniversitesi Kanser Enstitüsü Direktörlüğü için çalışma teklifi almışsa da, bu görev alımı gerçekleşmemiştir. ${ }^{132}$

\section{Sonuç}

Türk ve Macar halklarının ilişkileri çok uzun ve geleneksel bir dostluğa dayanmaktadır. Yeni kurulan Türkiye Cumhuriyeti'ni ilk tanıyan devletlerden biri olan Macaristan ile Türkiye'nin ilişkileri, Atatürk Dönemi’nde siyasal/ekonomik/kültürel alanlarda gelişerek ilerlemiştir. Atatürk döneminde kurulan bu dostane ilişkiler, zaman zaman dostluğunda ötesinde, "kardeşlik" sıfatına erişebilmiştir. Böyle bir perspektifte gelişen Türk-Macar

\footnotetext{
${ }^{125}$ Namal, agt, s.267; Saral, agt., 396-397.

${ }^{126} B C A, 30.10 .0 .0,201.375 .22$, Dosya:24222, 16.2.1946.

${ }^{127}$ Hasan Eren, Türklük Bilimi Sözlüğü- I. Yabancı Türkologlar, Türk Dil Kurumu Yayınları, S. 705, Ankara 1988, s.153.

${ }^{128} B C A, 30.18 .1 .2,128.7 .3,25.01 .1952$; “Janos Eckmann (21.VIII.1905-22.XI.1971)”, Türk Kültürü, Y. X, S. 111, Ocak 1972, s.186-189.

${ }^{129}$ Eren, a.g.e, s.169-171; Çoban, a.g.m, s.425-426.

${ }^{130} B C A, 30.18 .1 .2,12.42 .10$, Say1: 9563 , Dosya: 147-16, 21.06.1930; BCA, 30.18.1.2, 114.46.13,

Say1:3/6094, Dosya: 27-198, 30.06.1947; Yücel Namal, "Macar Türkolog Gyula Mészáros ve Türkiye'deki Calıșmaları", XI. Milli Türkoloji Kongresi Bildirileri, 11-13 Kasım 2014, C. 2, s.621-653.

${ }^{131} B C A, 30.18 .01 .02,113.38 .16$., Say1:3/5936, Dosya:27-255, 6.06.1947.

${ }^{132} B C A, 30.18 .1 .2$, Say1:3/6065, Dosya:27-271, 28.6.1947; Joszef Honti, Fatma Arın Namal; “ Efforts in 1947 to Make Prof. Dr. Ernestus de Balogh (1890-1964) Work For The University of İstanbul”, Orvostörténeti Közlemények -Communicationes de Historia Artis Medicinae, S. 182-185, Y. 2003, s.155-161.
} 
ilişkileri, İkinci Dünya Savaşı'nın atmosferinden dolayı gerilemişse de, dostluklarına gölge düşürememiştir. Siyasi ilişkiler problemsiz ilerlemiş, her firsatta iki ülke dostluğa dayalı ilişskilerini vurgulamışlardır.

İki ülkenin ekonomik ilişkileri, dönemin şartlarına uygun olarak kliring ve takas yöntemiyle gerçekleşmiş, ama ekonomi alanında Macar uzmanların rolü nicelik olarak oldukça fazla olmuştur. Savaş dolayısıyla ekonomik ilişkiler istenilen düzeyde yürütülememiş̧tir. $\mathrm{Bu}$ dönemde ihracat, ithalatın aksine büyük oranda primer (temel) ürünlerden oluşmaktadır. İhracat edilen primer mallar kategorisi için birkaç ürün üzerinde yoğunlaşılmıştır. Türkiye'nin primer mallar karşılığında sanayi malları almış olduğu görülmektedir.

İki ülkenin en verimli sahası kültürel ve sosyal ilişkiler olmuştur. Sosyal ilişkiler, iki ülkenin siyasi ve ekonomik ilişkileri üzerinde her dönem itici bir güç olmuştur. Bu dönemde Macar bilim insanları ve uzmanlarının Türkiye'ye çok değerli katkıları olduğu gibi, iki halk da başlarına gelen felakette birbirlerine her zaman yardım eli uzatmıştır.

Türkiye'nin dört bir köşesinde, çok geniş bir alanda çalışan Macar uzmanlar, Türkiye'nin modernleșme ve gelișme sürecinde niteliği yüksek görevler almışlardır. Bilimden eğitime, mimariden sanata, tarımdan mühendisliğe kadar birçok Macar bilim insanlarının, uzmanlarının ve teknikerlerinin emeği geçmiştir.

\section{Kaynakça}

Arşiv

$B C A$ (Başbakanlık Cumhuriyet Arşivi)

- 030.01 Başbakanlık Özel Kalem Müdürlüğü

- 030.10 Başbakanlık Muamelât Genel Müdürlüğü

- 030.18 Bakanlar Kurulu Kararlar1 ve Ekleri

TíTE (Türk İnkılap Tarihi Enstitüsü Arşivi)

Yayınlanmış Arşiv Belgeleri

Arşiv Belgelerine Göre Osmanlı'dan Günümüze Türk-Macar İlişkileri, Başbakanlık

Devlet Arşivleri Genel Müdürlüğü, İstanbul 2016.

\section{Resmi Yayınlar}

\section{Resmi Gazete}

\section{Gazeteler}

“Peşte Fuarı Aç1ldı”, Cumhuriyet, 27.4.1940, s.3.

"Peşte Elçimiz Geliyor" Cumhuriyet, 4.8.1943, s.3.

“Macaristan'da", Cumhuriyet, 30.10.1943, s.3.

“Parlak Törenler”, Cumhuriyet, 31.10.1943, s.1.

“Ruşen Eşref”, Cumhuriyet, 8.8.1943, s.1.

"Bir Macar Gazetesi Büyük Şefimizin Başarılarını Tahlil Ediyor”, Cumhuriyet, 15.8.1943, s.1. s.3

“Macar Elçisi İzmir Fuarına Gitti”, Cumhuriyet, 6.9.1943, s.2

“Macar Elçisi İzmir’de”, Cumhuriyet, 7.9.1943, s.3. 
“Eski Macar Başvekili”, Cumhuriyet,4.4.1944,s.1.

“Macaristan ve Türkiye”, Cumhuriyet, 2.12.1945, s.4.

“Ankara'da Macar Temsilcisi”, Cumhuriyet, 25.9.1946, s.3.

“Kızılayın Macar Fakirlerine Yardımı”, Cumhuriyet, 19.1.1946, s.1

“Macaristan’a Yapacağımız Yardım”, Cumhuriyet, 20.2.1946, s.1.

“Macaristan'a Yardım”, Cumhuriyet, 24.2.1946, s.1.

“Peşte Ticaret Odası Memurlarına Yardım”, Cumhuriyet, 27.3.1946, s.3.

"Macarlara Yardım”, Cumhuriyet, 12.4.1946, s.2.

“Türk-Macar Dostluğu”, Cumhuriyet, 22.2.1947, s. 1.

“Macar Elçisi İtimadnamesini Takdim Etti”, Cumhuriyet, 5.2.1947,s.3.

“Macar Basını Acımızı Paylaşıyor”, Ulus 1.1.1943, s.4

“Macar Elçisi Fuarımızı Ziyaret Etti”, Ulus, 9.9.1943, s.2.

“Macarlar Türkiye ile Ananevi Dostluğa Sadık”, Ulus, 7.8.1944, s.2.

“Times'in Peşte Muhabiri Milyonlarca Macar'ın Açlık Tehdidi Altında Olduğunu Yaziyor,", Ulus, 7.4.1946,s.3.

“Macaristan'a Yardım Hakkında Bir Açıklama”, Ulus, 3.5.1946, s.2.

Volume 12

“Macarlara Türk Yardımı”, Ulus, 11.4.1946, s.2.

“Üniversiteliler Tarafından Macar Gençlerine Yardım”, Ulus, 5.5.1946, s.1.

“Erbaa Zelzelesi Macaristan'da Büyük Teessür Uyandırdı”, Akşam, 1.1.1943, s.2.

“Macar Sefiri Fuarda Bir Ziyafet Verdi”, Akşam, 8.9.1943, s.1.

“Macaristan'da Açlık”, Akşam, 9.1.1946, s.2

“Zelzele Dolayısıyla Bir Macar Gazetesi Taziyede Bulunuyor”, Vakit, 1.1.1943,s4.

“Budapeşte'de Açlık”, Vakit, 3.1.1946, s.2.

Asım Us, “ Türk-Macar Kardeşlik Duygusu”, Vakit, 1.4.1946, s.1-s.4.

“Macaristan'da Kitl1k”, Tanin, 3.1.1946, s.3.

\section{Kitaplar}

ÇOLAK, Melek; 1956 Macar İhtilali ve Türkiye, Nehir Yayınları, İstanbul 2009.

EREN, Hasan; Türklük Bilimi Sözlügü̈-I Yabancı Türkologlar, TDK Yayınları, Say1:705, Ankara 1988.

; Türk Dil Kurumu'ndaki Eski Anılar, TDK Yayınları, Ankara 2008.

ERKUN, Fethi Vecdet, Budapeşte'den Ankara'ya, Türk-Macar Dostluk Derneği Yayınlar1:2, Ankara,1999. 
GÜNGÖRMÜŞ Naciye, Macaristan'da Değişim ve Demokrasiye Geçiş (1989-2009), Köksav Yayınları, Ankara 2010.

HAZAİ, György, Tarih Boyunca Macar-Türk Bă̆ları, Budapest 1963.

JOÓAndrás,“ 20. Yüzyılda Kendisine Sığınma Hakkı Tanınan Macar Başbakanı MiklósKállay (1942-1944)", Türkiye’de Kendilerine Siğınma Hakkı Tanınan Macar Mültecilerin Özyaşamlarından Özetler, (Çev: Yılmaz Gülen), MagyarTörökBarátiTársaság, Budapest 2010.

KOÇAK, Cemil; Türkiye'de Milli Şef Dönemi (1938-1945), Cilt:1,İletişim Yayınları, İstanbul 2012, s.164.

MÓLNAR, Miklós, A Concise History of Hungary, (TranslatedbyAnnaMagyar), Cambridge University Press, Sixth Printing, Cambridge 2009.

ÖNEM, Nizam, İki Turan: Macaristan ve Türkiye'de Turancılık, İletişim Yayınları, İstanbul 2005.

RÁSONYİ, László, Macarlar ve Türkler, Macar Balkan Encümeni Yayımı, Budapeşte, 1944.

SZÉKELY, András, A Brief History of Hungary, Translated: Elek Helvey, Archives of Corniva Kiadó, 4th Edition, Budapest 1973.

\section{Makeleler}

ANTAL, Pergel, "Egy magyar barát török diplomata Sevket Fuat Kecsedzsi 18921965 ”, Érdi Lap, XI. évfolyam No. 15 (15 augusztus 2013), s.8.

ÇOBAN, Erdal, “Türkiye'de Bir Macar Türkolog: Tibor Halasi-Kun”, DTCF Dergisi, Cilt:56, Say1:2, ss.413-439.

ÇOLAK, Melek; "Atatürk Döneminde Kültürel, Siyasi ve Ekonomik Bakımdan Türk-Macar İlişkileri (1919-1938)", Muğla Üniversitesi Sosyal Bilimler Enstitüsü Dergisi, Cilt:1, Sayı:2, Güz 2000, ss.61-72.

; “Atatürk'ün Vefatı ve Macaristan'daki Yankıları", Atatürk Araştırma Merkezi Dergisi, Say1:57, Kasım 2003, ss.1009-1016.

; “Cumhuriyet'in İlk Y1llarında Türkiye-Macaristan İktisadi İlişkileri”, Askeri Tarih Araştırmaları Dergisi, Genel Kurmay Askeri Tarih ve Stratejik Etüd Başkanlığı Yayınları, Sayı:4 Yı1:2 Ağustos 2004,ss.47-54.

; "II. Dünya Savaşı Yıllarında Macar Yahudileri ve Türkiye", Karadeniz Araştırmaları, Sayı:27, Güz, 2010, ss.77-87.

DREISZIGER, N.F, “The Second World War and its Aftermath", Hungarian Studies Review, Vol:XXVIII, Nos.1-2, Spring-Fall 2001,ss.36-45.

DURAN Alev- İsmail Köse, "Lajos Kossuth ve Macar Mülteciler", Selçuklu Araştırmaları Dergisi, USAD, S.6, 2017, s. 291-314 
HONTI, Jószef, Fatma Arın Namal, “ Efforts in 1947 to Make Prof. Dr. Ernestus de Balogh (1890-1964) Work For The University of İstanbul”, Orvostörténeti Közlemények-Communicationes de Historia Artis Medicinae, Say1:182-185, Y11:2003, ss.155-161.

GOSZTONY, Peter, "Horty, Hitler and the Hungary of 1944”, Canadian-American Review of Hungarian Studies, No:1, Vol: II, Spring 1975, ss.43-58.

“JanosEckmann (21.VIII.1905-22.XI.1971)", Türk Kültürü, Y11:X, Say1:111, Ocak 1972, ss.186-189.

JÓZSEF, Szabó, "Magyar-Török Kulturális Kapcsolatok A Második Világháborút Követően", Világtörténet, 2004. Tavasz-Nyár, ss. 53-62.

KURTASLAN, Zafer, “ Türk Keman Okulunun Oluşum Süreci ve Temsilcileri”, Türkiyat Araştırmaları Dergisi, Say1:26, Güz 2009, ss.409-429.

KUŞÇU, Ayşe D.;"Prof. Dr. Mekki Şerif Baştav”, Türk Yurdu, Aralık 2010, Cilt:30, Say1:280, s. 71-74.

NAMAL, Yücel, “ Macar Türkolog Gyula Mészáros ve Türkiye'deki Çalışmaları”, XI. Milli Türkoloji Kongresi Bildirileri, 11-13 Kasım 2014, Cilt:2, ss.621-653.

NECATİGİL, Behçet, “ Balkan Ülkeleri Edebiyatlarından Türkçeye Çeviriler”, Türk Dili, Çeviri Sorunları Özel Sayısı, Say1:322, Temmuz 1978, ss.126-154.

NYÍRİ, Mária, “ Oldukça Uzak Geçmişten Başlayarak 1996’ya Kadar Tarih Boyunca Türk-Macar İlişkilerine Kısa Bir Bakış”, Türk Dünyası Araştırmaları, Sayı:149, Nisan 2004, ss.211-222.

ÖZERDİM, Sami N., “ Macar Yazınından Çeviriler”, A.Ü Siyasal Bilgiler Fakültesi Basın ve Yayın Yüksek Okulu Yıllık 1979-1980, S.B.F. Basın ve Yayın Yüksek Okulu Basimevi, Ankara 1981, ss.247-262.

UÇAN, Ali, “ Türk-Macar Kültür/Müzik İlişkilerine ve Türk-Macar Karş1laştırmalı Halk Müziği Araştırmalarına Bir Bakış”, Türk-Macar Halk Müziğinin Karşılaştırmalı Araştırması, Macaristan Cumhuriyeti Ankara Büyükelçiliği Yayını, Ankara 2005, ss.46-88.

YALÇIN, Osman; “ İkinci Dünya Savaşı'nda İsmet İnönü ve Churchill Arasında Yapılan Adana Görüşmesi”, Ankara Üniversitesi Türk İnkllâp Tarih Enstitüsü Atatürk Yolu Dergisi, Say1:47, Bahar 2011, ss.701-731.

YILDIRIM, Seyfi; "Cumhuriyet Döneminde Türk-Macar İlişkileri Çerçevesinde İstihdam Edilen Macar Uzmanlar", Cumhuriyet Tarihi Araştırmaları Dergisi/ CTAD, Y11:8, Say1:15, Bahar 2012, s.121-150.

\section{Tezler}

SARAL, Emre, Türkiye-Macaristan İlişkileri (1920-1945), Yayımlanmamış Doktora Tezi, Hacettepe Üniversitesi, Ankara 2016. 
İkinci Dünya Savaşı Sırasındaki Türkiye-Macaristan İlişkileri

NAMAL, Yücel, Türk Kaynakları Işı̆ğında Türk-Macar İlişkileri(1923-1950), Yayımlanmış Doktora Tezi, Ankara Üniversitesi, Ankara 2013. 